\title{
Hepatic damage following profound hypothermia and extracorporeal circulation in man
}

\author{
D. P. E. K I N G S LE Y ${ }^{1}$ \\ From the Department of Pathology, St. Bartholomew's Hospital, London
}

Much investigation has been carried out during the past few years into the changes in serum enzyme levels following hypothermia for cardiac surgery. Alterations in serum enzyme levels have been correlated with the type of operation, the anaesthetic, the rate of perfusion, and the age and weight of the patient, but little attempt has been made to associate these changes with damage to specific tissues (Schlief and Kamm, 1957 ; Snyder, Barnard, Varco, and Lillehei, 1958 ; Quinn, Sirak, Shabanah, and Frajola, 1960 ; Baer and Blount, 1960 ; Fraser, Rossall, Black, and Dvorkin, 1962).

Evidence is given in this paper to suggest that the liver contributes to the raised serum enzyme levels following circulatory arrest, that the degree of damage which occurs is in some cases sufficient to cause obstructive jaundice, and that the patient's age and pre-operative state of health play an important part in post-operative morbidity from this cause.

\section{METHODS AND PROCEDURE}

Investigations were carried out on 19 patients who underwent cardiac surgery under profound hypothermia with extracorporeal circulation. and circulatory arrest using Hurt's modification of Drew's technique (Drew and Anderson, 1959 ; Hurt, 1962). The periods of arrest varied between 27 and 71 minutes. The techniques of anaesthesia and perfusion have been described elsewhere (Langdon and Kingsley, 1964). The types of operation performed are. shown in Table I. A further five patients, used as controls, underwent mitral valvotomy without extracorporeal circulation or hypothermia.

Samples of blood were taken pre-operatively, at the beginning and end of arrest, at the end of perfusion, and at six, 24, and 48 hours.post-operatively. Further samples were taken on alternate days thereafter. A sample of pump blood was also obtained before perfusion began. During the operation samples were obtained through a disposable blood transfusion giving-set needle, size $15 / 10$, inserted into the right atrial return line. In each case the blood was centrifuged immediately at 3,000 r.p.m. and the serum was

1Present address: Department of Surgery. St. Bartholomew's Hospital, London
TA B L E I OPERATIONS UNDERTAKEN

\begin{tabular}{|c|c|c|c|}
\hline \multicolumn{3}{|c|}{ Type of Operation } & No. of Patients \\
\hline $\begin{array}{l}\text { Aortic valve replacement } \\
\text { Mitral valve replacement } \\
\text { Total correction of Fallot' } \\
\text { Aortic valve repair } \\
\text { Aortic valvotomy } \\
\text { Relief of subvalvular aorti } \\
\text { Correction of anomalous p }\end{array}$ & $\begin{array}{ll}\cdots & \cdots \\
\text { tralogy } & \cdots \\
\cdots & \cdots \\
\text { enosis } & \cdots \\
\text { nonary vein }\end{array}$ & $\begin{array}{l}\cdots \\
\cdots \\
\cdots \\
\cdots \\
\cdots \\
.\end{array}$ & $\begin{array}{r}10 \\
4 \\
2 \\
1 \\
1 \\
1 \\
1\end{array}$ \\
\hline
\end{tabular}

separated. The following estimations were carried out on each sample:

gLUTAMIC-OXALOACETIC TRANSAMINASE (SGOT) Estimated by the method of Babson, Shapiro, Williams, and Phillips (1962), using the Transac kit.

LACTIC DEHYDROGENASE (LDH) Total and isoenzyme fractions estimated by the heat fractionation method of Wróblewski and Gregory (1961). In this paper $\mathrm{LDH}_{1}$ will refer to the isoenzyme which migrates fastest during electrophoresis at $p \mathbf{H} 8 \cdot 6$.

ALPHA-HYDROXYBUTYRATE DEHYDROGENASE

Estimated by the method of Rosalki (1962).

(HBD)

ISOCITRIC DEHYDROGENASE (ICD) Estimated by the colorimetric method of Bell and Baron (1960).

BILIRUBiN Estimated by the method of Dangerfield and Finlayson (1953).

ALKALINE Phosphatase Estimated on the AutoAnalyzer (Technicon), susing the method of Powell and Smith (1954).

plasma haemoglobin Determined by Dacie's modification of the method of Bing and Baker (Bing and Baker, 1931 ; Dacie and Lewis, 1963).

\section{RESULTS}

The most striking finding in this study was the strong relationship shown between the changes in serum enzyme level and the age of the patient under investigation.

Accordingly, the results of the enzyme estimations are considered individually, whilst attention is drawn to this association by considering the 19 patients in four groups, according to age. These were 0-20 years (four patients), 21-40 years (five patients), 41-50 years (four patients), and over 50 


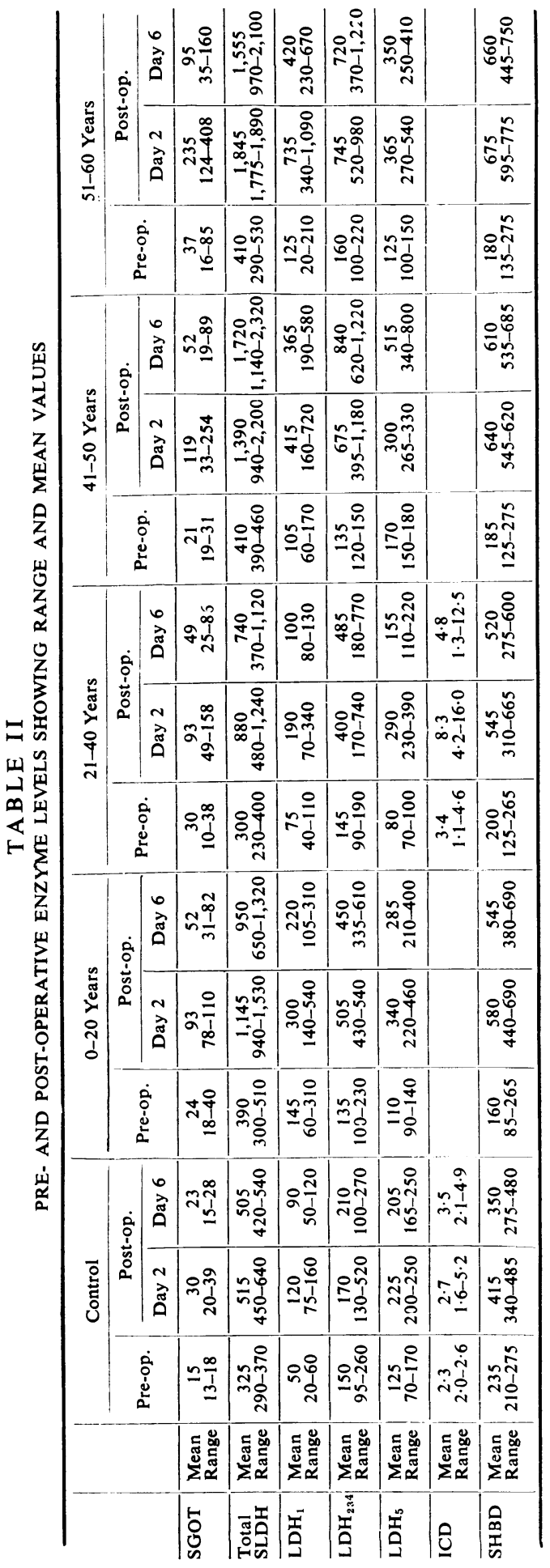

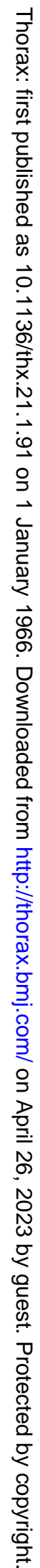


years (six patients). The results are summarized in Table II and Figures 1 to 6.

glutamic-oxaloacetic transaminase Pre-operative levels were all within normal limits with one exception, and there was no significant rise with age. Post-operatively transaminase levels were raised both in the controls and in patients undergoing hypothermia. In the younger groups the rise with age was not marked, but in the over-50 age-group this rise was statistically significant (Fig. 1).

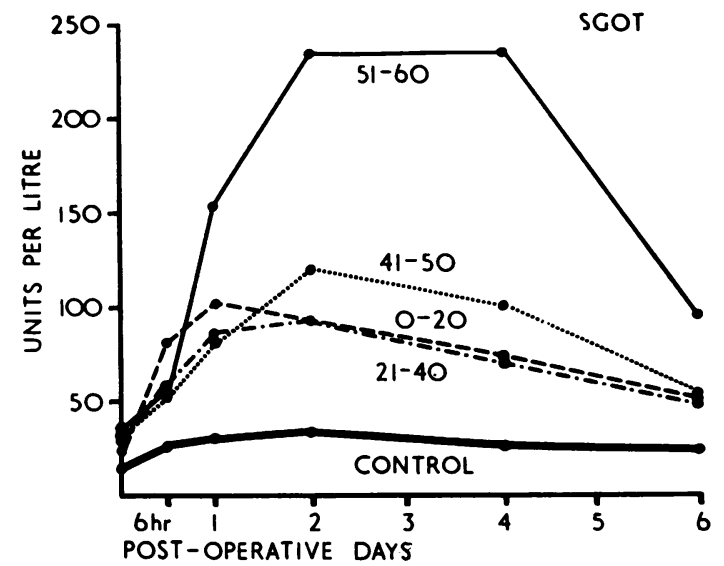

FIG. 1. Glutamic-oxaloacetic transaminase: pre- and post-operative enzyme levels.

LACTIC DEHYDROGENASE Total LDH showed changes similar to transaminase in both the controls and those undergoing hypothermia. The levels reached a maximum by the second postoperative day and only began to fall after the fourth day (Fig. 2).

$\mathrm{LDH}_{1}$ showed the same pattern as total LDH, pre-operative levels being within normal limits and post-operative levels in patients undergoing hypothermia rising significantly with age (Fig. 3).

Pre-operative levels of $\mathbf{L D H}_{5}$ were within normal limits. Post-operatively the rise in levels of the controls was more marked than with the $\mathrm{LDH}_{1}$ fraction. There was no statistical difference between the controls and those undergoing hypothermia (Fig. 4).

ISOCITRIC DEHYDROGENASE Estimations confirmed a similar pattern to the changes in $\mathbf{L D H}_{1}$. Postoperatively the changes in the levels of the controls were minimal, whereas patients undergoing hypothermia showed significant rises, the levels increasing with age (Fig. 5).

ALPHA-HYDROXYBUTYRATE DEHYDROGENASE Preoperative levels were within normal limits, but

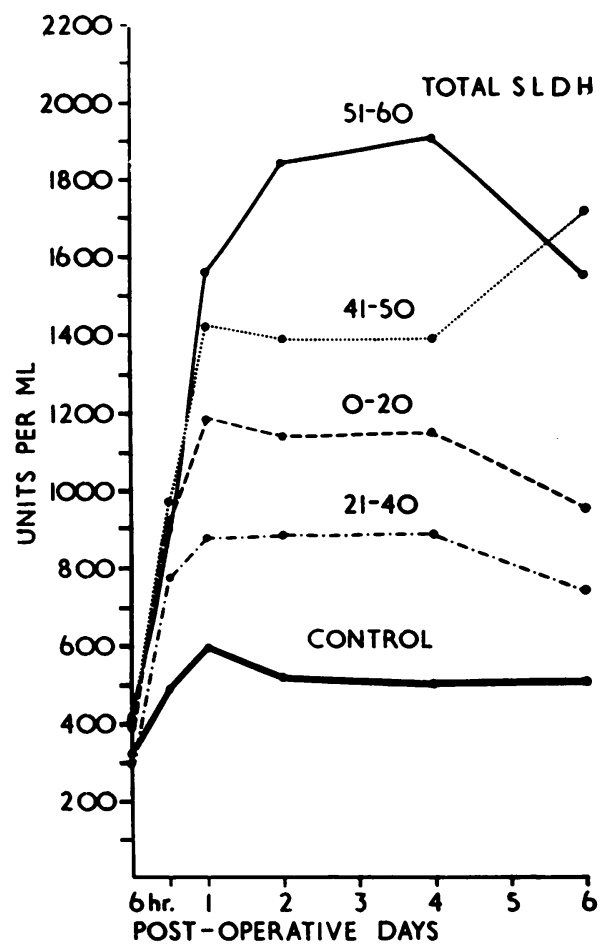

FIG. 2. Total lactic dehydrogenase: pre- and postoperative enzyme levels.

post-operatively the changes were similar to those occurring in $\mathrm{LDH}_{5}$. There was a slight but not significant increase in enzyme level with age among the patients undergoing hypothermia (Fig. 6).

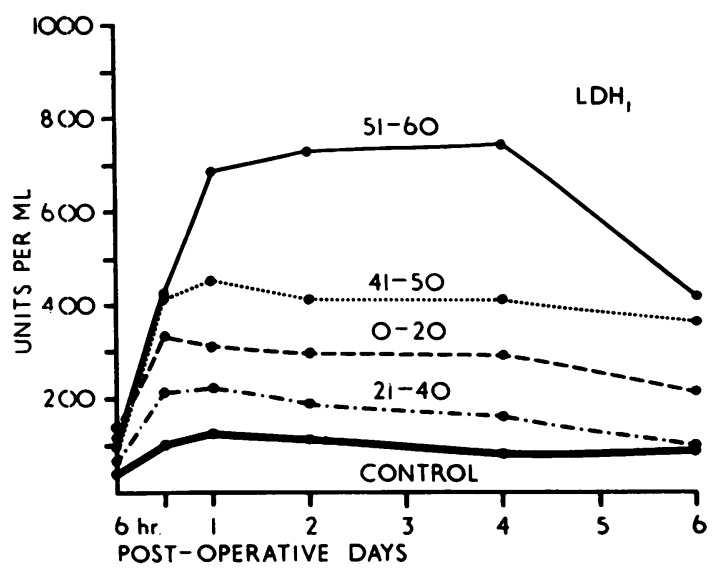

FIG. 3. $L D H_{1}$ : pre- and post-operative enzyme levels.

BILIRUBIN Bilirubin levels began to rise at the end of circulatory arrest. The levels of total and conjugated bilirubin six hours post-operatively and at their highest point are shown in Table III. 
TABLE III

BILIRUBIN, ISOCITRIC DEHYDROGENASE AND ALKALINE PHOSPHATASE LEVELS IN INDIVIDUAL PATIENTS

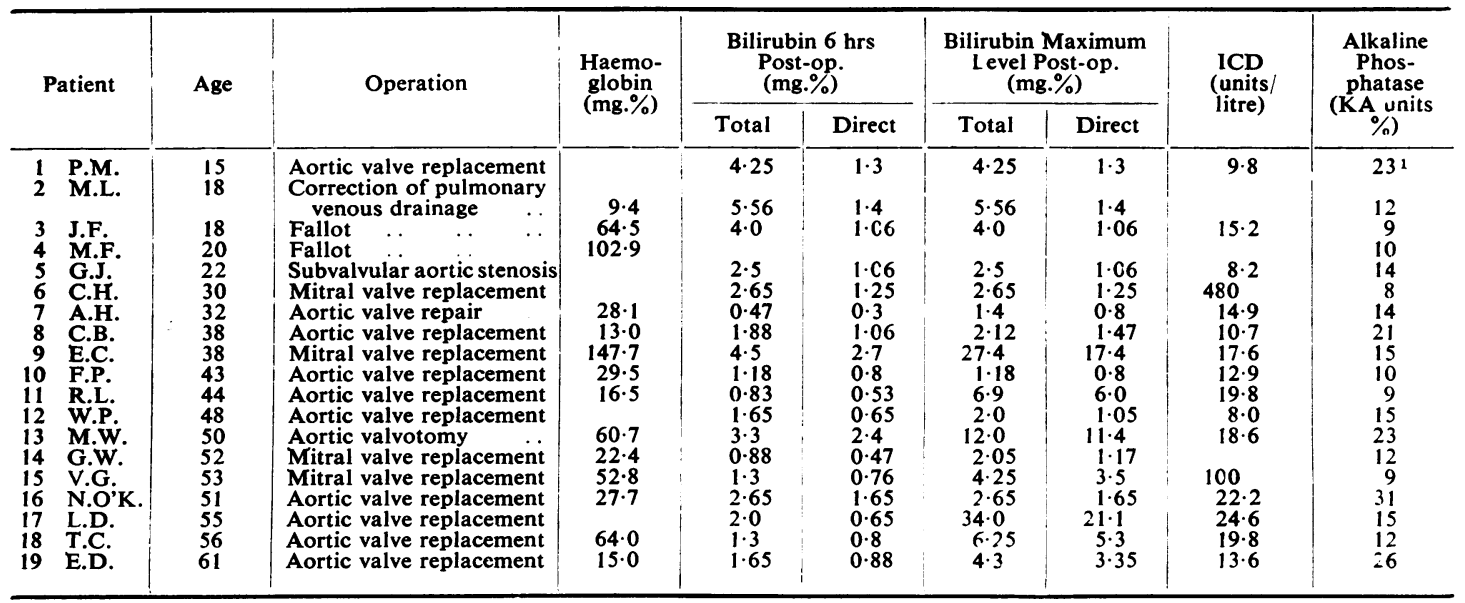

${ }^{1}$ Pre-operative level

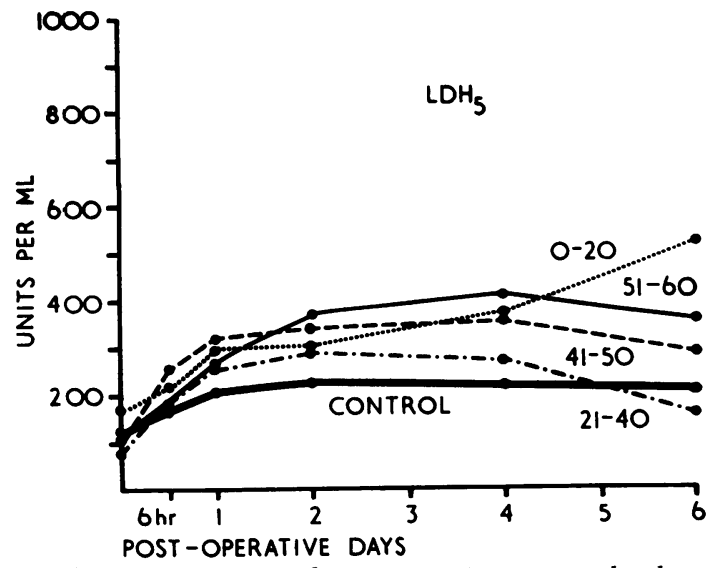

FIG. 4. $L D H_{5}$ : pre- and post-operative enzyme levels.

ALKALINE PHOSPhatase In nine patients the alkaline phosphatase rose post-operatively to above normal limits (13 King-Armstrong uni:s per $100 \mathrm{ml}$.). This rise began at about the end of the second post-operative week, was maximal between the second and fourth weeks, and thereafter gradually returned to normal.

Plasma haEmoglobin This was estimated during perfusion and showed that in many cases some haemolysis did occur. However, the highest level obtained was $140 \mathrm{mg} . / 100 \mathrm{ml}$. (less than $1 \%$ free haemoglobin), while the mean value was approximately $50 \mathrm{mg} . / 100 \mathrm{ml}$. (0.3\% free haemoglobin). Plasma haemoglobin estimated post-operatively was always below $20 \mathrm{mg}$. $/ 100 \mathrm{ml}$.

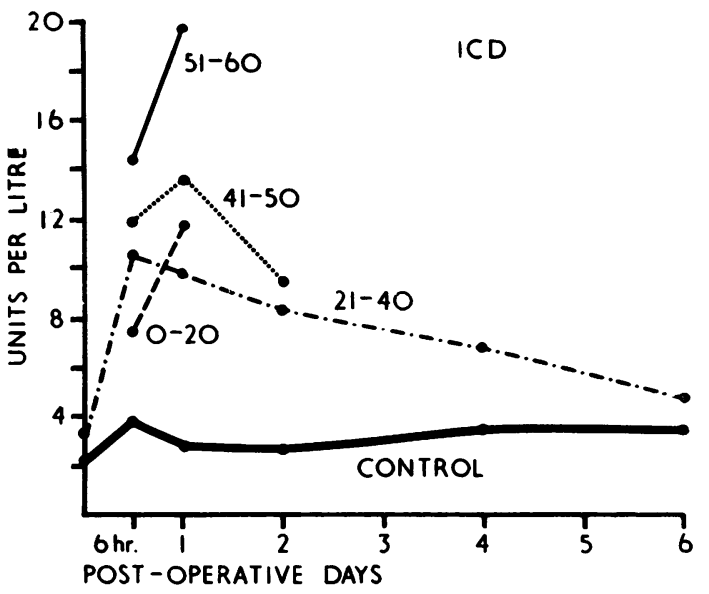

FIG. 5. Isocitric dehydrogenase: pre- and post-operative enzyme levels.

PUMP BLOOD In every case the levels of serum enzymes, bilirubin, and haemoglobin were within normal limits.

POST-MORTEM STUDIES Of the 19 patients who underwent hypothermia, three died post-operatively, the deaths occurring on the eighth, sixteenth and thirty-first days respectively. All three had biochemical evidence of severe hepatic damage. Macroscopically the liver appeared normal, but histological examination showed marked centrilobular necrosis. These changes are shown in Figures 7 to 9.

HEART FAILURE The relation between right-sided heart failure, found in patients pre-operatively, 


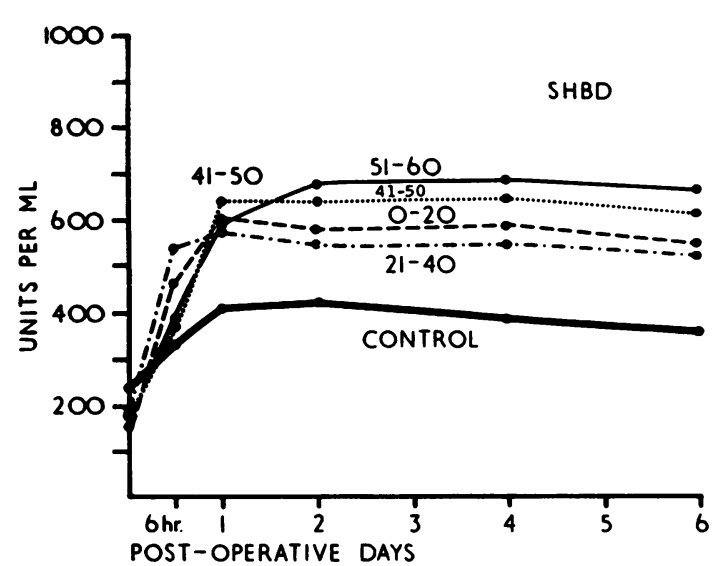

FIG. 6. Alpha-hydroxybutyrate dehydrogenase: pre- and post-operative enzyme levels.

the number of these patients over the age of 50 , and the post-operative biochemical and postmortem studies is shown in Table IV.

\section{DISCUSSION}

Much work has been done to determine whether a rise in serum enzyme levels signifies overt cell necrosis or whether minor and completely reversible histological changes are also capable of producing raised levels. For instance, Nydick, Ruegsegger, Wróblewski, and LaDue (1957) havz found that the level of glutamic-oxaloacetic transaminase in experimental cardiac infarction is roughly proportional to the amount of myocardial necrosis, whereas coronary insufficiency does not produce a rise. Pagliaro and Notarbartolo (1962), investigating alpha-hydroxybutyric dehydrogenase levels following myocardial infarction, found a similar parallel between the enzyme level and the degree of necrosis. Furthermore, in another paper Nydick, Wróblewski, and LaDue (1955) showed that the loss of even one gramme of cardiac muscle leads to significantly raised levels of enzymes in the serum.

Alternatively, evidence has been put forward that hypoxia without cell necrosis might cause a liberation of enzymes into the serum due to an increase in the permeability of the cell membrane. Vacca (1963) obtained significantly raised enzyme levels in healthy volunteers following heavy exercise for six to eight minutes; he also found that the levels had returned to normal within 24 hours. The short duration of raised enzyme levels found in this experiment is unlike that obtained in tissue necrosis. Rosalki (1963) investigated the levels of glutamic-oxaloacetic transaminase, lactic dehydrogenase, and alpha-hydroxybutyric dehydrogenase following myocardial infarction and found that the average time for these enzymes to return to normal was $5 \cdot 4,11$, and 13 days respectively. On balance it seems that the observation of an abnormally raised and sustained serum enzyme level may be equated with definitive cell necrosis.

In the series reported in this paper the enzymes investigated showed levels persistently raised for several weeks post-operatively, and by inference it seems that the liberation of these enzymes is due mainly to tissue necrosis and not primarily to increased permeability of the cell membrane.

Of the many enzymes which can be measured in the serum, none is tissue specific; but it is known that the estimation of a number of enzymes simultaneously enables comparisons to be made between changes in the levels of each, and thus it is possible to obtain a fairly accurate picture of the site of tissue destruction. For example, Bell, Shaldon, and Baron (1962) have found that in liver damage both transaminase and isocitric dehydrogenase levels rise, whereas following myocardial infarction the transaminase level is raised while the isocitric dehydrogenase level remains within normal limits. Similarly an LDH: HBD ratio of less than $1 \cdot 2: 1$ is found in myocardial infarction, whereas a ratio great $2 r$ than $1 \cdot 5: 1$ is associated with liver damage.

Although many enzymes are ubiquitous in distribution, Wróblewski and Gregory (1961) have shown that the isoenzymes of lactic dehydrogenase vary in concentration in any one organ within very narrow limits. They found that the slow moving isoenzyme $\mathbf{L D H}_{1}$, estimated electrophoretically, was present in the liver almost to the exclusion of the other isoenzymes, and that the

TABLE IV

RELATION OF HEPATIC FUNCTION TO PRE-OPERATIVE HEART FAILURE

\begin{tabular}{|c|c|c|c|c|c|c|}
\hline Patients & Total & $>50$ Years Old & $\begin{array}{l}\text { Bilirubin } \\
>3 \mathrm{mg} . \%\end{array}$ & $\begin{array}{c}\text { Alk line } \\
\text { Phosphatase } \\
>13 \text { KA Units } \%\end{array}$ & \begin{tabular}{|l|} 
ICD \\
$>15$ Units $/ \mid$ \\
litre
\end{tabular} & $\begin{array}{l}\text { Post-mortem } \\
\text { Confirmation of } \\
\text { Hepatic Damage }\end{array}$ \\
\hline $\begin{array}{l}\text { Without heart failure } \\
\text { With failure previously but not }\end{array}$ & 12 & 1 & 3 & 1 & 3 & 1 \\
\hline $\begin{array}{l}\text { at operation } \\
\text { With failure at operation } \quad \ldots\end{array}$ & $\begin{array}{l}3 \\
5\end{array}$ & $\begin{array}{l}1 \\
4\end{array}$ & $\begin{array}{l}0 \\
4\end{array}$ & $\begin{array}{l}1 \\
2\end{array}$ & $\begin{array}{l}0 \\
4\end{array}$ & $\begin{array}{l}0 \\
2\end{array}$ \\
\hline
\end{tabular}


fast moving isoenzyme $\mathrm{LDH}_{5}$ was the main component in heart muscle.

Using these methods, analysis of the levels obtained post-operatively in this series reveals much of the origin of the enzymes in the various groups. In the controls the isocitric dehydrogenase $\vec{F}$ remains within normal limits and the $\mathbf{L D H}_{1}$ rises? only minimally; the glutamic-oxaloacetic transaminase, total lactic dehydrogenase, and alpha- $\frac{\bar{\sigma}}{\sqrt{0}}$ hydroxybutyric dehydrogenase levels are signifi-

FIGs 7 to 9. High-power photomicrographs of the liver architecture taken post mortem.

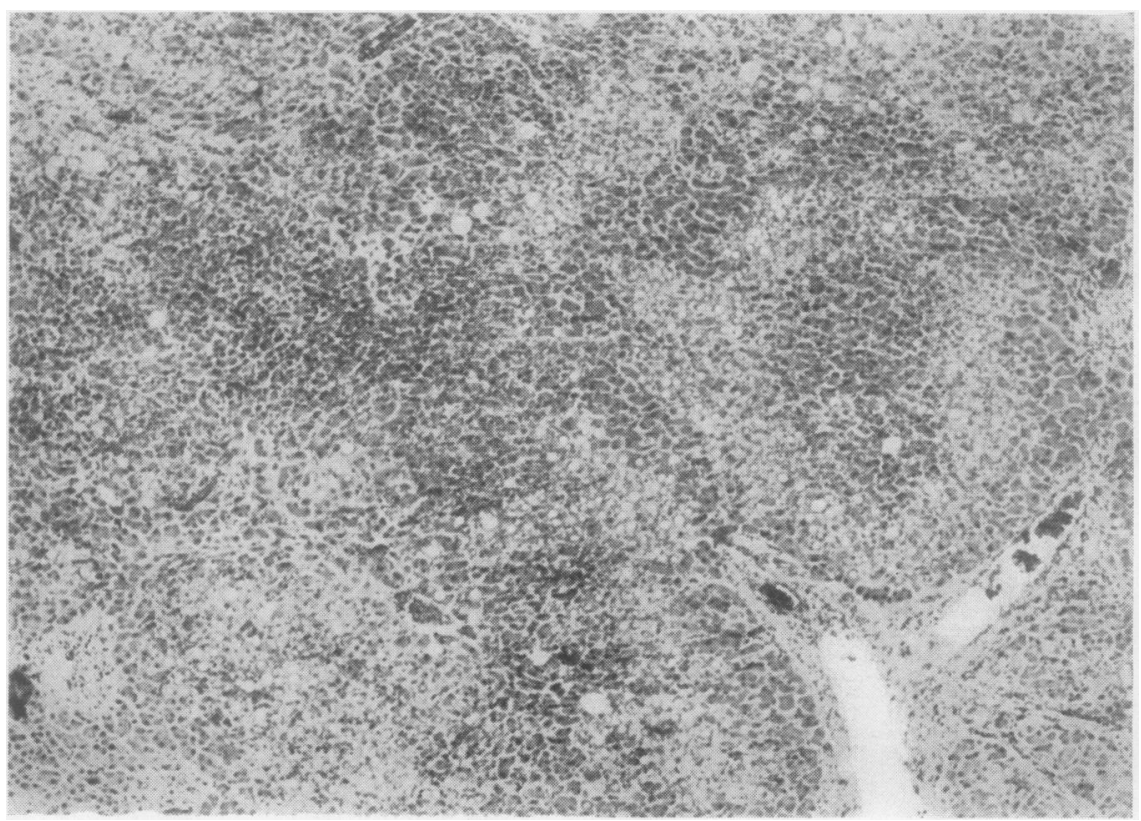

FIG. 7. Patient died on 8 th post-operative day.

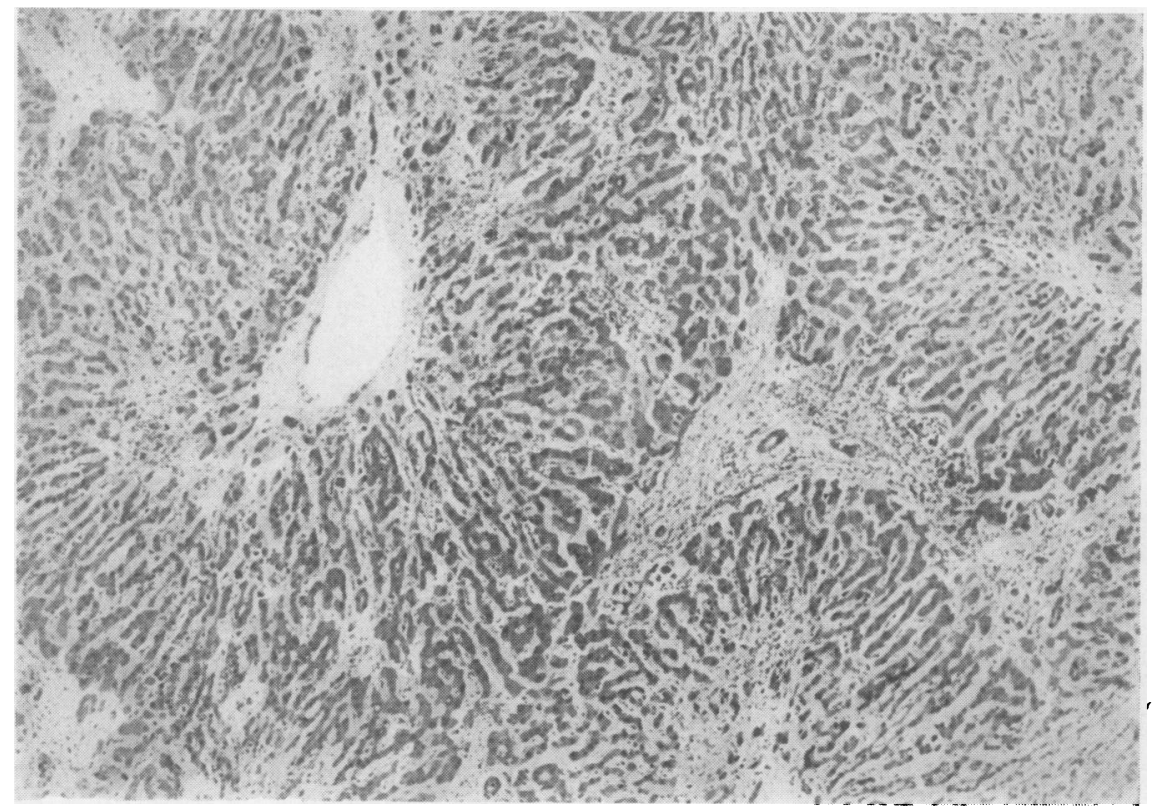

FIG. 8. Patient died on 15 th post-operative day. 


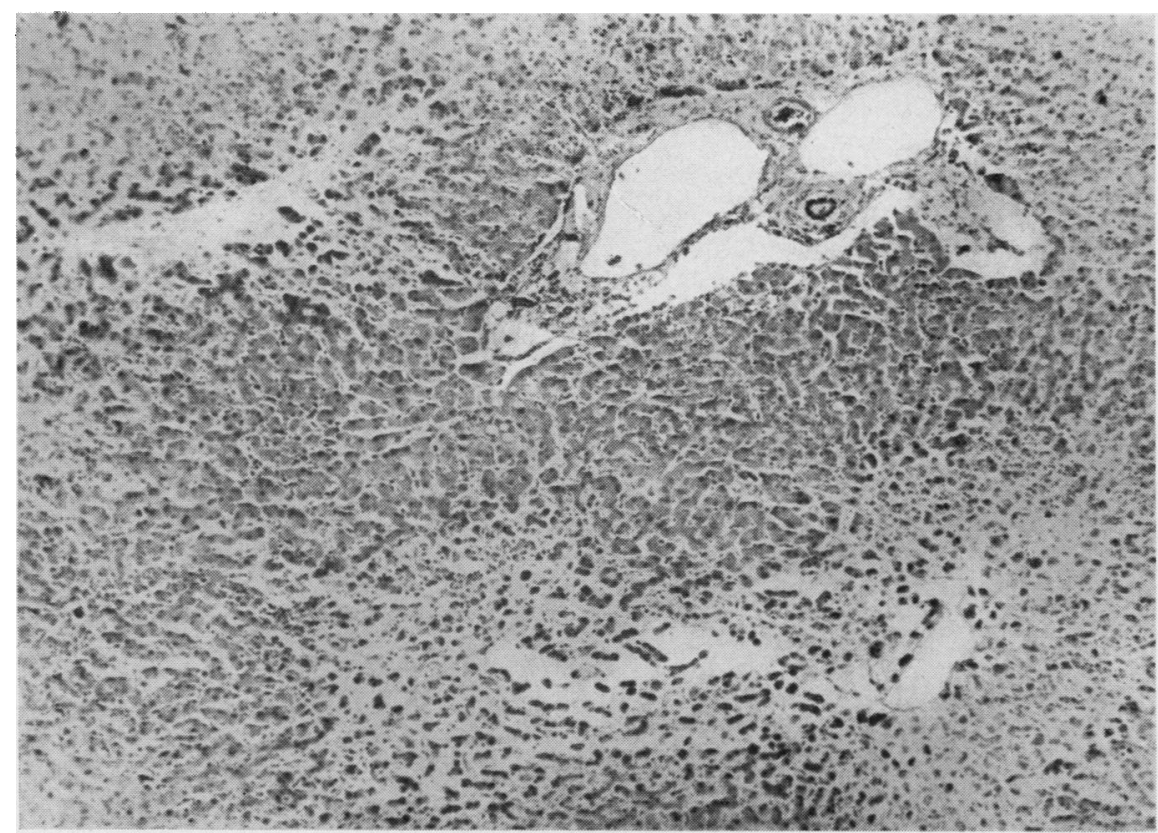

FIG. 9. Patient died on 31st post-operative day.

cantly raised and the total $\mathrm{LDH}: \mathrm{HBD}$ ratio is $1 \cdot 2: 1$, suggesting the myocardium as the sole source of these enzymes.

However, in the patients undergoing hypothermia the picture is more complex, for all the enzymes estimated were found to rise postoperatively. These enzymes undoubtedly come from a number of different sources; the heart and the liver can be identified with certainty, and the evidence is as follows.

In the myocardium, the $\mathrm{LDH}_{5}$ and HBD levels are raised above those of the controls, but the rise with age is not significant.

In the liver, the total LDH: HBD ratio is above $1 \cdot 2: 1$. Furthermore it shows a significant rise with age to a peak of $2.75: 1$ in the oldest age-group. Whereas the HBD only rises to three times the normal level, there is a six-fold rise in the level of total LDH. The increase in the ratio of total LDH : HBD above that in the controls is accounted for, at least in part, by the release of enzymes from the liver. Two of these enzymes, $\mathrm{LDH}_{1}$ and ICD, also rise significantly with age, there being a seven-fold increase in each enzyme in the oldest age-group.

Haemolysis does not cause more than a minimal change in the enzyme levels. Previous work carried out by us (Kingsley, Cooke, and Vartan, 1965) has shown that with a mean serum haemoglobin level of $50 \mathrm{mg} . / 100 \mathrm{ml}$, obtained during perfusion, glutamic-oxaloacetic transaminase rises by only $10 \%$, and total lactic dehydrogenase and alpha-hydroxybutyric dehydrogenase both rise only $40 \%$ above normal levels.

Further evidence of liver damage, occurring during profound hypothermia, is obtained from studies of the serum bilirubin and alkaline phosphatase and from post-mortem histological changes in the liver.

Changes in the serum bilirubin showed two separate patterns. An initial rise occurred at the end of perfusion, was maximal within 24 hours, and then decreased. This rise occurred in all patients and was not accompanied by clinical jaundice, except in the youngest three patients who were polycythaemic pre-operatively. Crosby and Howard (1954) have calculated that for every $10 \mathrm{mg} . / 100 \mathrm{ml}$. of haemolysis there is a rise in serum bilirubin of $0.35 \mathrm{mg} . / 100 \mathrm{ml}$; thus it seems probable that this early rise is accounted for by haemolysis.

A second rise in the bilirubin level, accompanied by clinical jaundice, occurred in seven patients. This rise began on the second to sixth day postoperatively and lasted for up to three weeks. The percentage of conjugated bilirubin was high, and of these seven patients five were over the age of 50 years.

The alkaline phosphatase rose post-operatively above normal limits in nine patients, five of these 
being over the age of 48 years. However, in no patient did the rise in this enzyme reach abnormal levels before the end of the second post-operative week.

Post-mortem histological studies of the livers of the three patients who died showed marked centrilobular necrosis. In the patient who died on the eighth day, active cell necrosis alone was present. In the patient who died on the thirty-first day, however, tissue repair was well advanced. The changes in these livers corresponded with the length of time between operation and the death of each patient. Biochemical studies on these patients, all of whom became jaundiced, showed very high levels of $\mathbf{L D H}_{1}$ and ICD. Two of the three also had raised alkaline phosphatase levels, while the third died on the eighth day, several days before this enzyme would have been expected to become abnormal.

Pre-operative right-sided heart failure is a possible contributory factor to the degree of postoperative liver damage. Eighty per cent. of the patients who were in heart failure at the time of operation showed post-operative evidence of marked liver damage, whereas only $25 \%$ of those without evidence of pre-operative heart failure showed liver damage in any marked degree.

\section{SUMMARY}

Investigations were carried out on 19 patients who underwent cardiac surgery under profound hypothermia and circulatory arrest for a number of cardiac abnormalities. Five other patients, used as controls, underwent mitral valvotomy without perfusion. SGOT, LDH isoenzymes, HBD, ICD, bilirubin, and alkaline phosphatase were estimated pre-operatively and post-operatively at intervals of one or two days. Both the controls and the hypothermia patients showed evidence of myocardial damage with raised levels of $\mathrm{LDH}_{5}$ and HBD. The levels in the hypothermia patients were slightly in excess of those in the controls. Evidence of liver damage was obtained from the levels of $\mathrm{LDH}_{1}$ and ICD. Post-operatively both enzymes were found to be normal in the controls but raised in all hypothermia patients, the rise being most marked over the age of 50 and in those with preexisting heart failure. Bilirubin and alkaline phosphatase levels were also raised in some hypothermia patients as compared with the controls. Confirmation of liver damage was obtained post mortem in three patients.

I wish to thank Professor W. G. Spector, Dr. A. B. Anderson, and Dr. T. B. Boulton for their help and advice during this project, Mr. J. E. A. Wickham for helpful criticisms of this paper, and the Department of Pathology for their help in carrying out some of the estimations, especially Dr. Angela Vartan and Miss Elsa Hutchinson. I also wish to thank Mr. O. S. Tubbs and Mr. I. M. Hill for their continued encouragement and for permission to carry out the investigation on their patients. This project was helped by a grant from the joint Medical and Surgical Research Committee of St. Bartholomew's Hospital.

\section{REFERENCES}

Babson, A. L., Shapiro, P. O., Williams, P. A. R., and Phillips, G. E. (1962). The use of a diazonium salt for the determination of glutamic-oxalacetic transaminase in serum. Clin. chim. Acta, 7, 199.

Baer, H., and Blount, S. G. (1960). The response of serum glutamic oxalacetic transaminase to open-heart operation. Amer. Heart $J$., 60, 867.

Bell, J. L., and Baron, D. N. (1960). A colorimetric method for determination of isocitric dehydrogenase. Clin. chim. Acta, 5, 740 Shaldon, S., and Baron, D. N. (1962). Serum isocitrate dehydrogenase in liver disease and some other conditions. Clin. Sci., 23, 57.

Bing, F. C., and Baker, R. W. (1931). The determination of hemoglobin in minute amounts of blood by Wu's method. J. biol. Chem., 92, 589.

Crosby, W. H., and Howard, J. M. (1954). The hematologic response to wounding and to resuscitation accomplished by large transfusions of stored blood. A study of battle casualties in Korea. Blood, $9,439$.

Dacie, J. V., and Lewis, S. M. (1963). Practical Haematology, 3rd ed. Churchill, London.

Dangerfield, W. G., and Finlayson, R. (1953). Estimation of bilirubin in serum. J. clin. Path., 6, 173 .

Drew, C. E., and Anderson, I. M. (1959). Profound hypothermia in cardiac surgery; report of three cases. Lancet, 1, 748.

Fraser, R. S., Rossall, R. E., Black, W., and Dvorkin, J. (1962). Serum transaminase response to cardiac surgery using cardiopulmonary bypass. J. thorac. cardiovasc. Surg., 43, 810.

Hurt, R. L. (1962). Apparatus for profound hypothermia by the Drew technique. Lancet, 1, 783,

Kingsley, D. P. E., Cooke, J., and Vartan, A. E. (1965). The effects of haemolysis on some plasma and serum enzymes in man. Clin. chem. Acta, 12, 489.

Langdon, L., and Kingsley, D. P. E. (1964). Changes in serum and urinary potassium levels during profound hypothermia in man J. clin. Path., 17, 257.

Nydick, I., Wróblewski, F., and LaDue, J. S. (1955). Evidence for increased serum glutamic oxalacetic transaminase activity following graded myocardial infarction in dogs. Circulation, 12, 161 .

- Ruegsegger, P., Wróblewski, F., and LaDue, J. S. (1957) Variation in serum glutamic oxaloacetic transaminase activity in experimental and clinical coronary insufficiency, pericarditis, and pulmonary infarction. Circulation, 15, 324.

Pagliaro, L., and Notarbartolo, A. (1962). Alpha-hydroxybutyric dehydrogenase in the diagnosis of myocardial infarction. Lancet, 1,1043 .

Powell, M. E. A., and Smith, M. J. H. (1954). The determination of serum acid and alkaline phosphatase activity with 4-aminoantipyrine (A.A.P.). J. clin. Path., 7, 245.

Quinn, J. W., Sirak, H. D., Shabanah, E. H., and Frajola, W. J. (1960). Transaminase values following open-heart surgery. Ann. Surg., 152, 45.

Rosalki, S. B. (1962). A simple colorimetric method for the determination of serum alpha-hydroxybutyric dehydrogenase activity. J. clin. Path., 15, 566.

(1963). Serum alpha-hydroxybutyric dehydrogenase: A new test for myocardial infarction. Brit. Heart J., 25, 795.

Schlief, H., and Kamm, P. (1957). Die Aktivität der Serum-GlutamatOxalacetat-Transaminase und -Milchsäuredehydrogenase nach Herzoperationen. Klin. Wschr., 35, 1083.

Snyder, D. D., Barnard, C. N., Varco, R. L., and Lillehei, C. W. (1958). Serum transaminase patterns following intracardiac surgery. Surgery, 44, 1083.

Vacca, C. (1963). Sulla possibilità che 'stress' diversi, specie l'ipossia permettano la fuoriuscita di enzimi intracellurari per aumento della permeabilità della membrana cellurare senza necrosi tissurale. Riv. Med. aeronaut., 26, 443.

Wróblewski, F., and Gregory, K. F. (1961). Lactic dehydrogenase isozymes and their distribution in normal tissues and plasma and in disease states. Ann. N.Y. Acad. Sci., 94, 912. 